\title{
Simultaneous Equation Model for Economic Calculation of Households of Independent Rubber Farmers in Mineral Land in Kampar Regency, Riau Province, Indonesia
}

\author{
Heriyanto $^{1, *}, \mathrm{Asrol}^{2}$ \\ ${ }^{1,2}$ Departemen of Agribussines, Universitas Islam Riau, Pekanbaru, 28284. Indonesia
}

* Corresponding author : heriyanto@agr.uir.ac.id

Telp ; 082388011877

Received: Sept 14, 2019; Accepted: May 5, 2020

DOI 10.25299/jgeet.2020.5.2.3791

\begin{abstract}
Rubber is a plantation crop which is mostly a source of community income in Kampar District. As a source of household income, rubber farming is managed by households independently. This study generally aims to design models and government policy strategies in the development of smallholder rubber plantations on land typology mineral land conditions on the economic decision making of rubber farmer households. Specifically, this study was conducted with the aim of analyzing the characteristics of independent smallholders and internal and external dominant factors that influence the allocation of working time, income and household expenses of rubber farmers. This research was conducted using a survey method located in Kampar District. The data used in this study consisted of primary data obtained using the interview method. Samples were taken by simple random sampling method with 60 rubber farmers. Descriptive analysis and Economic Decision Model of Rubber Farmer Households using the simultaneous equation model approach with the Two Stages Least Square (2SLS) analysis method were performed to answer the research objectives. The results showed that only internal factors of farm households are responsive to household economic decisions. There are no external factors included in the model that are responsive to the economic decisions of rubber farming households in Kuantan Singingi Regency regarding the aspects of production, working time allocation, income and expenditure of rubber farming households. From the aspect of production, no responsive internal or external factors were found, but the biggest effect was the number of productive rubber stems. From the aspect of work time allocation, internal factors that are responsive to influence are the total outpouring of farmer work, outpouring of farm family work in businesses and the workforce of farmer households. Furthermore, from the aspect of farmer's household income the responsive internal factors that influence it are the farmer's household income in the business. then what influences household expenditure is outflow of work in business, farmer education, wife education and total rubber farmer income. The policy implications of increasing rubber prices and outpouring of family work in the business have the most positive impact. While the increase in wages for workers outside the family has a negative impact on the household economy.
\end{abstract}

Keywords: Household Economy, Dominant Factors, Rubber.

\section{Introduction}

The agricultural sector in Indonesia continues to be demanded to play a role in the national economy through the formation of Gross Domestic Product (GDP), foreign exchange earnings, supply of food and industrial raw materials, poverty alleviation, employment provision and increasing community income.

At the provincial level, Riau does not differ greatly from the national level. In 2016, the area of rubber was ranked second after oil palm with an area of 504,553 ha. In the last five years (2012-2016), the total area, production and number of farmers cultivating rubber plants in Riau Province tended to decrease. In 2012, the area of rubber plantations was 128,520 ha with a production of 392,781 tons, decreasing to 90,877 ha with a production of 333,155 tons. The number of farmers cultivating rubber plants also declined from 276,210 households to 244,560 households (Badan Pusat Statistik, 2017b). At the level of Kampar Regency, it is not much different from the provincial level. In 2012 the largest plantation area was occupied by oil palm plants with an area of 190,486 Ha. While the rubber plant is in second place with an area of $92,509 \mathrm{Ha}$. In the period 20122016 the area of rubber plantations decreased. In 2012 the area of rubber plantations was 91,328 hectares and in 2016 the area of rubber plants was 91,143 hectares (Badan Pusat Statistik, 2017a). The decreasing area and production of rubber plants, as well as farmers who are working on rubber plants are thought to be due to the conversion of rubber land to oil palm.

Development in the plantation sector is directed to further accelerate the rate of production growth both from large plantations, private and state plantations and community nucleus estates as well as self-managed plantations to support industrial development, as well as increase the utilization and preservation of natural resources (SDA) in the form of land and water. The role of the plantation sector is so great for increasing the use of farmers and supplying raw materials for the domestic industry and as a source of foreign exchange (Heriyanto, 2017).

Various problems that occur will affect production acquisition, allocation of work time, income, and the level of welfare of farmers. The level of welfare of farmers can be seen from the expenditure of household consumption. In other words, households are faced with the problem of allocating work time, income and expenses. The economic decisions of rubber farming households in relation to the allocation of work time, household income and expenditure, are theoretically influenced by internal and external factors. A rubber farming household that uses labor from outside the household expects workers with high productivity, but with low wages. Instead a worker tends to expect a job with a high level of wages. 
Comparison between the price level of rubber also determines the decision of rubber farmers to keep doing rubber plantation business or not. If the price of rubber products produced is quite high while the price of inputs is relatively cheap, so that production costs are less than the gross income obtained, then the business is profitable. The higher the level of profits obtained, the rubber plantation business will increasingly develop. Various external shocks that affect the production process will affect the allocation of work time, will further affect the acquisition of income and ultimately will affect the amount and pattern of household expenditure.

Based on the background description and problems above, in general this research objective is to analyze the household economy which includes the allocation of working time, income and expenditure of rubber farmer households on mineral land. Specifically the purpose of this study is to Analyze the characteristics of rubber farmers and internal and external dominant factors that affect the allocation of work time, income and household expenditure.

\section{Literature Review}

\subsection{Agricultural Development Concepts}

Some economists claim that agricultural development is believed to be able to drive economic growth while at the same time helping to reduce income inequality, poverty and unemployment (Poonyth, D, R. Hassan \& Calcaterra, 2001; Romeo, M, 2000, 2001; Warr, 2006). Some agricultural development strategies that are expected to achieve this are Agricultural-Led Growth strategies (Poonyth, D, R. Hassan \& Calcaterra, 2001), stategi Agriculture-Based Development by (Poonyth, D, R. Hassan \& Calcaterra, 2001; Romeo, M, 2000, 2001), and stategi Agricultural Demand Led Industrialization (ADLI) by (Adelman, 1984; Julia,2016).

The concept of agricultural development includes land resources, nuftah plasma, water, technology, financing and human resources (HR). Agricultural development aims to increase farmers' income and welfare through increasing agricultural production. This increase in agricultural production in addition to meeting domestic industrial raw materials that continue to grow also aims to increase foreign exchange from exports of agricultural products. One of the steps that can be taken to increase the contribution of the agricultural subsector is the production of plantation crops (Soekanda, 2001).

Strategi Agricultural-Led Growth (Poonyth, D, R. Hassan \& Calcaterra, 2001) emphasized that the agricultural sector as a leading sector in economic development because the agricultural sector is a driver for economic growth. Therefore the agricultural sector needs to get the main attention compared to other sectors because of its potential in driving economic growth and job creation. Development of a productive agricultural sector and better rural areas is the key to the growth of the agricultural sector and is a precondition for successful economic development.

Strategi Agriculture-Based Development (Romeo, M, 2000,2001 ), based on the consideration that in many lowincome countries the majority of the population is in rural areas, where the agricultural sector is the main source of life. This strategy is more effective than the import substitution strategy or the export-led industrialization strategy, based on the consideration that it provides opportunities for income generation, directly or indirectly, for rural populations. Through this strategy public resources are increased to be allocated to the agricultural and rural sectors and is expected to increase agricultural productivity and income of rural populations.

The role of the agricultural sector in economic development includes: (1) increasing the availability of food or food surplus for domestic consumption, (2) releasing excess labor to the industrial sector, (3) being a market for industrial products, (4) increasing domestic savings, (5) increasing trade (sources of foreign exchange), and (6) improving the welfare of rural people (Jighan, 1994).

Research on the household economy of farmers has been done by researchers, such as the household economy of rice farmers. Households in paddy farming in production are determined by labor in the family, the amount of seeds, fertilizers and pesticides. The difference between households is that households of paddy rice farmers use more labor in the family (Elinur, Asrol, \& Heriyanto, 2017; Heriyanto, 2018).

Next Heriyanto (Heriyanto, 2017), has conducted research on the analysis of the efficiency of rubber production factors in Kampar Regency, Riau Province. The results of his study showed that the dominant factors affecting rubber production in Kampar District were the number of plants, age of plants, number of workers and investment. The production factor is the number of plants, and the number of workers is technically inefficient, allocative, and economically. The use of fertilizers tends to be technically and economically efficient, butallocativelyinefficient.

Rubber farm house hold economic research analyzes from the aspects of production, farm household work time allocation, the use of non-family labor, non-farm income, and household expenditure that includes food and non-food expenditure. This research will produce a comprehensive economic model of smallholder farmers' households that have not been studied by researchers before. This study also recommends policies relating to the development of smallholder rubber in the context of increasing the household income of rubber farmers.

\subsection{Household Economy}

Understanding farm households is very important because the characteristics are very unique and complex. In this case the household has resources that can provide satisfaction and can be shared among household members. In addition, households in increasing their satisfaction must have alternatives so that households have many choices. Household economic activities such as production activities as a farming company, consumption activities as consumers and as labor providers. In carrying out these activities the household carries out the principle of utility maximization with budgetary or resource constraints (Nakajima, 1989).

Farmer house hold as an economic unit that acts as a producer and consumer. Households as producers carry out production activities and as consumers carry out consumption activities simultaneously. This will be different from the company's activities. Companies as economic units only carry out the activities of producing goods and services to achieve maximum profits.

(Becker, 1965) formulating an agricultural household model (economic model of agricultural households) that integrates production and consumption activities as a whole and the use of labor in the family is preferred. This household economic model uses a number of assumptions, namely: First, household satisfaction in consuming is not only determined by the goods and services obtained in the market, but also is determined by various commodities produced in the household. Second, the element of satisfaction is not only goods and services, but includes time. Third, time and goods or services can be used as factors of production in household production activities. And fourth, households act as producers as well as consumers.

Meanwhile, (Barnum \& Squire, 1978) revealed that the household economic model can be used to analyze the economic behavior of agricultural companies which all use paid labor and sell all products produced to the market. Unlike subsistence agriculture which relies on family labor, so there is no market surplus.

(Singh, I. \& Strauss, 1986)arrange the agricultural household economic model as a basic model of the household economy. In the model stated that household utilities are 
determined by consumption of goods and services produced by households, consumption of goods and services purchased in the market, and consumption of leisure (leisure time).

households include activities of production, consumption and allocation of labor in the family carried out simultaneously with more complex estimation techniques. Estimation of the model uses two stage least squares (3SLS) or three stage least squares (3SLS) estimation techniques. Rice farm household economics studies using 2 SLS estimation techniques were carried out by (Faradesi, 2004; Rochaeni \& Erna M, 2005) in Cianjur Regency and Bogor City. Economic research on farm households is also applied to farm households in plantation crops, such as rubber and oil palm farm households, research conducted by (Elinur \& Asrol, 2015a; Husin \& Dwi Wulan, 2011; Khaswarina, 2017).

Rice farm household economics research analyzes the allocation of work time in farming, production and household expenditure. The allocation of work time consists of the equations of outpouring of family labor in lowland rice farming, outpouring of non-farm family labor. The production equation is influenced by the use of rice production factors. Equation of rice farmers household expenditure consists of food and nonfood expenditure. However, this research has not accommodated household expenditure in terms of health, education and leisure time (leaisure) (Faradesi, 2004; Rochaeni \& Erna M, 2005)

The economic research of rubber farmer households consists of a flow of farmer's household working time on rubber farming and non-farming. Household income consists of income from rubber, non-rubber and non-farming farming. Rubber farmer household expenses consist of food, non-food expenditure, education expenditure, farm investment and farmer household savings. The model does not yet accommodate the demand for workers outside the family and clothing, housing and health and leisure expenses. This research is still in the village scope (Husin \& Dwi Wulan, 2011; Khaswarina, 2017; Heriyanto et al., 2019; Ningsih et al., 2020)

The economic research of the oil palm farmer household builds a model consisting of the equal allocation of farm household work time, oil palm production, labor demand outside the farmer's family, farmer's household income and farmer household expenditure. The study of the household economics of oil palm farmers includes four aspects: First, the demand for labor is distinguished from labor within the family and outside the family. Second, include outflow of family work outside the business and income from outside the oil palm farm. Third, include business investment, education investment and household savings, i.e. saving money in financial institutions on the household expenditure side. And fourth, house hold consumption consists of food, non-food consumption and recreation (Elinur \& Asrol, 2015a; Heriyanto \& Asrol, 2019 Karya, Heriyanto, \& Asrol, 2019).

This economic study of rubber farming households combines the economic models of rice farming households and rubber and oil palm farming households. The economic model of rubber farming households consists of complex equations that accommodate household expenditure that are in accordance with household economic phenomena, among others: first, the rubber production equation is influenced by production factors consisting of the amount of crops, fertilizers, pesticides and internal labor. Second, the equality of household time allocation for rubber farmers from the allocation of working time for households in farming and outside farming. Third, household income from rubber farmers consists of rubber farming income, non-rubber farming income and non-farming income. Fourthly, the household expenditure of paddy farmers consists of food expenditure, clothing expenditure, education expenditure, health and recreation expenses. Fifth, the rubber farming household economic model also includes expenditures for farming investment, because in general rubber farmers in the study area set aside their income for the farming. From several farmer household economic studies, this study has similarities and differences with previous farmer household economic research. The similarity is that this research has accommodated all farm household household economic activities which include production, consumption and work time allocation aspects. The advantage of this research is that it includes clothing and health and recreation expenses, which have not been accommodated by previous studies.

\subsection{Review of Previous Studies on Home Economics}

Studies of the household economy have been carried out both partially and simultaneously such as, (Chuzaimah, 2006; Elinur, 2004; Heriyanto, 2017; Husin \& Sari, D, 2011; Koestiono, 2004; Siti \& Erna, 2005) analyzing policy simulations of the household economy of agriculture. The results of the policy simulation imply that the policy of increasing output prices is not effective in increasing the amount of production that can be sold to the market. This is due to additional benefits due to rising prices of agricultural output and technological improvements are more allocated as labor costs.

(Priyanti, B.M, Y.Syaukat, \& S.U, 2007) conducting a Farmer Household Economy Model Study on Crop-Livestock Integration Systems. the results of the study that the farm household household economic model is able to explain reciprocal farm household income obtained from maximizing satisfaction with production constraints, time allocation and income distribution. This includes aspects of production, allocation of use of family labor, use of inputs and production costs, income and income as well as farm household expenses. This model is very useful to identify the factors that influence the decisions of farm households, especially in increasing income simultaneously and integrated between crop and livestock businesses.

(Husin \& Sari, D, 2011), conducted a study on the Economic Behavior of Rubber Farmer Households in Prabumulih in Workforce Allocation, Production and Consumption with the result that the behavior of farm household household time allocation behavior was influenced by total household expenditure, rubber land area, non-rubber farm land area, rubber farming income and number of children under five. Farmer household production behavior is influenced by the area of rubber land, non-rubber farming land area, outpouring of family labor on rubber farming, the use of fertilizers and pesticides. Farmer household consumption behavior is influenced by total household income, time spent working by household members on rubber farming and number of household members. Several variables that were responded to elasticly by the variable of work time spent were rubber farming income, total household expenditure and non-rubber farming land area. Whereas the variable which is responded elasticly by household expenditure is total household income and expenditure for food consumption.

Research conducted by (Elinur \& Asrol, 2015b) about the economic decisions of oil palm farmer households in the village of Indra Sakti Kecamaan Tapung, Kampar Regency The economic model of the household that he built includes aspects of production, location of work time, use of labor within and outside the family, household expenses consisting of food and non-food expenditure. The research has not included expenditure on clothing, housing, education, health, and recreation. Overall expenditure is aggregated in food expenditure. This research is still in the scope of the village.

(Khaswarina, 2017; Wahyudy, 2019), conducting research on the household economics of ex-UPP TCSDP rubber farmers in Koto Damai Village, Kampar District. The economic model of the constructed household has included the production equation, allocation of work time, income in and out of farming, and food expenditure, education expenditure, non-food and 
household savings. The model does not yet accommodate the demand for workers outside the family and clothing, housing and health and leisure expenses. This research is still in the village scope.

\section{Research methods}

The location of the study was determined proportionally, namely in the Kampar District the Kampar District was chosen with consideration that the Kampar Regency was the second largest rubber plantation area after Kuantan Singingi Regency in Riau Province. To achieve optimal results, this research is expected to be funded within one year.

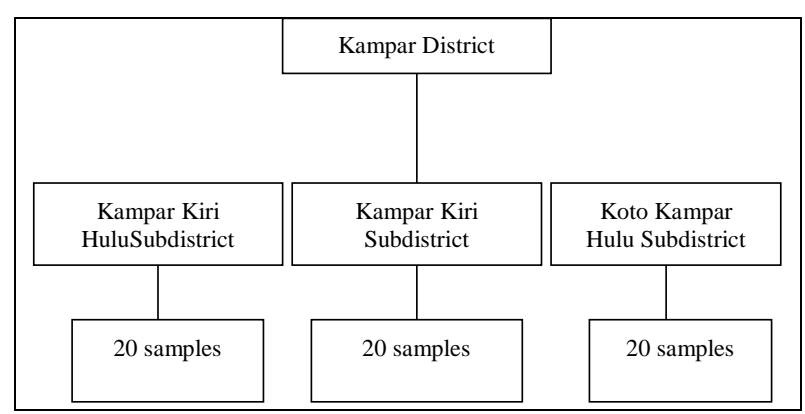

Fig 1. Number of Rubber Farmers Samples in Kampar District

Sampling in this study was conducted using a multy-stage purposive sampling method with criteria having an area of 1-3 Ha with a rubber plant age of 13-25 years. Samples were taken in 3 districts, namely Kampar Kiri Hulu Subdistrict, Kampar Kiri Hilir Subdistrict and XIII Koto Kampar Subdistrict, because the three districts are rubber production centers in Kampar Regency. Each sub-district took 20 rubber farmers and a total sample of 60 rubberfarmers.A clearer scheme for rubber farming household sampling ispresented in the figure above.
The type of data collected is cross section data. Primary data were obtained from direct interviews with respondents, namely rubber farming households using a prepared questionnaire. Besides that, secondary data from a number of related institutions were also collected, such as: the Plantation Agency, the Central Statistics Agency and other sources. Secondary data are used to sharpen and support the analysis in this study.

\section{Data analysis}

To answer the objectives of the characteristics of independent rubber farmers the study was analyzed using descriptive analysis. with the tabulation method focused on explaining the pattern of work time allocation, income contribution and household expenditure patterns. The description of the pattern of rubber farm household household work time allocation includes the length (percentage) of work time allocated to businesses within and outside the rubber plantation business. Furthermore, the allocation of working time can be disaggregated according to household members (husband, wife and children).

Meanwhile, the descriptive analysis of income contribution is intended to get a picture of the amount of income contribution in the business and outside the rubber plantation business to the total income of rubber farmer households. Next the descriptive analysis of household expenditure patterns is focused on looking at the amount of income allocation that is reinvested in the rubber plantation business, consumption expenditure, savings, investment and leisure. The pattern of household consumption expenditure is further broken down according to commodity groups, namely food and non-food consumption. In addition, a descriptive analysis was also carried out relating to the general description of sample identity (age, education, number of family members and work experience).

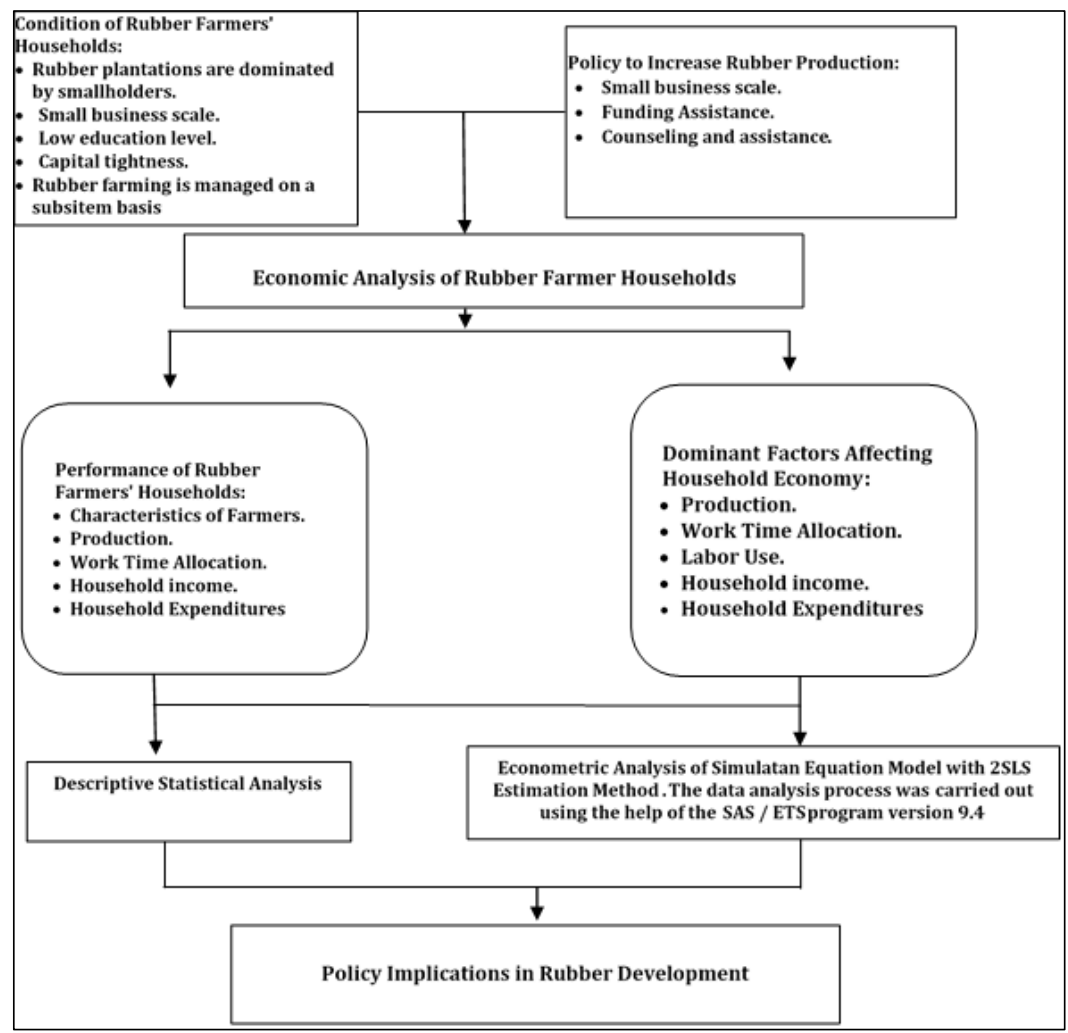

Fig 2. Frame work for Economic Analysis of Rubber Farmer House holds in Kampar District analyzed with the Simulatan Equation Model Econometry with 2SLS Estimation Method.

Furthermore, the household economic model that analyzes internal and external dominant factors that affect the allocation of work time, household income and expenditure and the impact of changes in government policy on household 
economic decision making are analyzed using the simultaneous equation approach with the Two Stages Least Square (2SLS) analysis method. The data analysis process was carried out using the help of the Statistical Analysis System Econometric Time Series (SAS / ETS) program version 9.4. Frame work for Economic Analysis of Rubber Farmer House holds in Kampar District analyzed with the Simulatan Equation Model Econometry with 2 SLS Estimation Method can be seen in the figure below.

\section{Results and Discussions}

\subsection{Characteristics of Independent Rubber Farmers}

The profile of rubber sample households (hereinafter referred to as rubber farm households) can be seen in Table 1 . Based on Table 1, it can be seen that the average age of heads of rubber farmer families is 48 years, thus it can be said that the average rubber farmers are at productive age. The average rubber farmer starts a rubber gardening business at the age of 32 years. Thus the average rubber farmer has been in business for 16 years, so it can be said that these rubber farmers have enough experience in running a rubber farming business.

Table 1. Characteristics of Rubber Farmer Households

\begin{tabular}{|c|c|c|c|}
\hline No. & Description & Unit & amou \\
\hline 1. & $\begin{array}{l}\text { Number of household respondents from rubber } \\
\text { farmers Gender: }\end{array}$ & Person & 60 \\
\hline & a. Men & Person & 58 \\
\hline & b. Women & Person & 2 \\
\hline 2. & The average age of rubber farmers & Year & \\
\hline 3. & $\begin{array}{l}\text { The average length of education of rubber farmers } \\
\text { The average length of education of a rubber farmer's } \\
\text { wife }\end{array}$ & Year & 9 \\
\hline & Average rubber farmer work experience & Year & \\
\hline 5. & Average household member is a rubber farmer & Year & \\
\hline 6. & $\begin{array}{l}\text { Average household workforce of rubber farmers } \\
\text { average household student is a rubber farmer } \\
\text { household }\end{array}$ & Person & \\
\hline & $\begin{array}{l}\text { Average area of rubber farmers } \\
\text { Origin: }\end{array}$ & Person & \\
\hline & a. Respondents were from Kampar Regency & Person & \\
\hline & $\begin{array}{l}\text { b. Respondents came from outside Kampar } \\
\text { District }\end{array}$ & $\begin{array}{l}\text { Hectare } \\
\text { Person } \\
\text { Person }\end{array}$ & 2 \\
\hline
\end{tabular}

Table 2 shows that the formal education of rubber farmers and wives of rubber farmers, respectively 10 years and 9 years. Thus it can be said that the education of rubber farmers and their wives is still low, ie only graduated from junior high school.

The average rubber farm household member is 6 people, including 4 people belonging to the labor force and 2 school children. In general, the household workforce of rubber farmers works both inside and outside the rubber farming business. The majority of rubber farming households are from Kampung Kabuapten, as many as 57 households. Only 3 rubber farmer households come from outside Kampar District. This indicates that the rubber farming business is dominated by people from within Kampar Distric.

Farmers who are working on this rubber have an average of 2 hectares of garden area. Rubber plantation land is own property with an average pattern of rubber plantation exploitation by rubber farmers and their families

\subsection{Internal and External Dominant Factors That Affect Working Time Allocation, Income and Expenditures of Rubber Farmer Households}

Table 2 shows the results of the estimation of the rubber production equation that rubber production is not responsive to the outflow of household work in the business (positive) and the number of productive rubber rods (positive). Although the elasticity values are not responsive, rubber production is more sensitive to changes in the number of productive rubber stems thanchanges in the flow of rubber farm family work in the business.
Variations in the work flow of rubber farming families in the rubber farming business, labor outside the family and the number of productive rubber stems have a positive effect on production. This illustrates that if the outflow of rubber farming family work in the rubber farming business, labor outside the family and the number of productive rubber stems increases, then rubber production will tend to increase.

Table 2. Internal and external dominant factors that affect the allocation of working time, income and expenditure ofrubberfarmerhouseholds

\begin{tabular}{|c|c|c|c|c|}
\hline Variabel & $\begin{array}{c}\text { Parameter } \\
\text { Estimate }\end{array}$ & $\mathrm{t}$ Value & $\operatorname{Pr}>|t|$ & Elasticity \\
\hline \multicolumn{5}{|l|}{ 1. Prodution } \\
\hline Intercept & -3481.0400 & -2.6600 & 0.0100 & \\
\hline Workflow in business & 1.6465 & 3.9400 & 0.0002 & 0.4018 \\
\hline External family labor & 1.4665 & 0.9600 & 0.3404 & \\
\hline Number of productive rubber stems & 10.9694 & 21.5900 & $<.0001$ & 0.9356 \\
\hline
\end{tabular}

$R 2=0.91199$, Fvalue $=193.44, \mathrm{Pr}>\mathrm{F}<.0001, \mathrm{Dw}=1.929889$

2. Workflow in business

\begin{tabular}{|l|r|r|r|r|}
\hline Intercept & 1917.9570 & 6.6000 & $<.0001$ & \\
\hline Rubber farm household income in the business & 0.0000 & 3.4500 & 0.0011 & 0.2279 \\
\hline Outflow of work outside the business & -0.6661 & -5.4400 & $<.0001$ & -0.2162 \\
\hline Rubber farm household work force & 118.2826 & 1.3100 & 0.1956 & \\
\hline
\end{tabular}

Rubber farm household work force

$\mathrm{R} 2=0.47965$, Fvalue $=17.21, \mathrm{Pr}>\mathrm{F}<.0001, \mathrm{Dw}=1.923857$

3. External family labor

intercept

Intercept Rubber farmers household income outside the bus The total outpouring of farmers' work

Rubber farm household wor

Rubber farmer work experience

4. Outflow of work outside the business

\begin{tabular}{|l|r|r|r|r|}
\hline Intercept & 1486.3600 & 1.7500 & 0.0852 & \\
\hline
\end{tabular}

\begin{tabular}{|l|r|r|r|r|}
\hline Intercept & 1486.3600 & 1.7500 & 0.0852 & \\
\hline Workflow in business & -0.8648 & -3.5500 & 0.0008 & -2.6644 \\
\hline
\end{tabular}

\begin{tabular}{|l|r|r|r|r|}
\hline Rubber farm household work force & -0.8648 & -3.5500 & 0.0008 & -2.6644 \\
\hline
\end{tabular}

$\mathrm{R} 2=0.4022$, Fvalue $=19.18, \mathrm{Pr}>\mathrm{F}<.0001, \mathrm{Dw}=1.650385$

5. Rubber farmers household income outside the business

Intercept

Rubber farm household income in hebusiness

Outlow of work outhold income in the busir

Uthlow of work outside the business

.38478 , Fvalue $=17.82, \mathrm{Pr}>\mathrm{F}<.0001, \mathrm{Dw}=1.558858$

6. Rubber farm household food consumption

Intercept

Total income of rubber farmer household

Number of family members

\begin{tabular}{|l|r|r|r|r|}
\hline Recreational expenditure of rubber farmers' househ & 1159123.0000 & 7.3000 & $<.0001$ & 0.3642 \\
\hline
\end{tabular}

\begin{tabular}{|l|r|r|r|r|}
\hline Wife's education & -204663.0000 & -2.0800 & 0.0426 & -85103.4607 \\
\hline
\end{tabular}

$\mathrm{R} 2=0.68107$, Fvalue $=29.36, \mathrm{Pr}>\mathrm{F}<.0001, \mathrm{Dw}=1.342588$

7. Non-food consumption of rubber farming households

\begin{tabular}{|l|r|r|r|r|}
\hline Intercept & -219881.0000 & -0.3000 & 0.7622 & \\
\hline Total income of rubber farmer households & 0.0030 & 1.3900 & 0.1714 & \\
\hline Number of family members & 841287.8000 & 5.2900 & $<.0001$ & 0.9657 \\
\hline Farmer Education & 38506.8700 & 0.7800 & 0.4366 & \\
\hline
\end{tabular}

Farmer Education

\begin{tabular}{|l|r|r|r|r|}
\hline Wife's education & 70762.1500 & 1.4600 & 0.1504 & \\
\hline
\end{tabular}

$\mathrm{R} 2=0.41041$, Fvalue $=7.52, \mathrm{Pr}>\mathrm{F}<.0001, \mathrm{Dw}=1.554068$

8. Educational investment

Intercept

\begin{tabular}{|l|r|r|r|r|}
\hline Total income of rubber farmer households & 274738.0000 & 0.2600 & 0.7948 & \\
\hline Number & 0.0024 & 0.4900 & 0.6256 & \\
\hline
\end{tabular}

\begin{tabular}{|l|r|r|r|r|}
\hline Number of school children & 2749502.0000 & 10.9600 & $<.0001$ & 0.8670 \\
\hline
\end{tabular}

Wife's education

\begin{tabular}{r|r|r|}
\hline 17597.3800 & 0.1900 & 0.8495 \\
\hline
\end{tabular}

$\mathrm{R} 2=0.76172$, Fvalue $=59.67, \mathrm{Pr}>\mathrm{F}<.0001, \mathrm{Dw}=1.522326$

9. Business investment

\begin{tabular}{|l|r|r|r|r|}
\hline Intercept & 48000314.0000 & 1.8000 & 0.0768 & \\
\hline Total income of rubber farmer households & 0.3015 & 2.4000 & 0.0197 & 0.2623 \\
\hline Workflow in business & 9396.2280 & 0.9100 & 0.3684 & \\
\hline Number of school children & -3478493.0000 & -0.6400 & 0.5249 & \\
\hline Business scale & 56847237.0000 & 4.4900 & $<.0001$ & 0.2945 \\
\hline R2 =0.47231, Fvalue $=12.31$, Pr $>\mathrm{F}<.0001$, Dw $=1.426565$ \\
\hline 10. Recreational expenditure of rubber farmers' households \\
\hline Intercept & 578960.6000 & 1.5000 & 0.1399 & \\
\hline Total income of rubber farmer households & 0.0009 & 0.8300 & 0.4079 & \\
\hline Workflow in business & -541.0220 & -3.4300 & 0.0012 & -4.7125 \\
\hline Outflow of work outside the business & -310.4160 & -3.1100 & 0.0030 & -0.8776 \\
\hline Farmer Education & 50376.3100 & 2.5500 & 0.0135 & 1.8117 \\
\hline Wife's education & 63828.4600 & 3.4500 & 0.0011 & 1312289.7143 \\
\hline R2 =0.55386, Fvalue $=13.41$, Pr $>\mathrm{F}<.0001$, Dw $=1.605136$ & \\
\hline 11. Savings & -6376491.0000 & -1.8600 & 0.0688 & \\
\hline Intercept & 0.0754 & 10.4900 & $<.0001$ & 1.5748 \\
\hline Total income of rubber farmer households & -0.1290 & -0.5800 & 0.5643 & \\
\hline Total consumption of rubber farmers & 2657819.0000 & 5.2700 & $<.0001$ & 0.8489 \\
\hline Interest rate & &
\end{tabular}

R2 $=0.7665$, Fvalue $=61.28, \mathrm{Pr}>\mathrm{F}<.0001, \mathrm{Dw}=1.300045$

Note: Significant at 10 percent level 
From the aspect of work time allocation shows that the outflow of family work in the business is not responsive to household income in the business (positive) and outflow of family work outside the business (negative). Furthermore outflow of family work outside of business is responsive to outflow of household work outside the business (negative) and the number of household workforce (positive) (Table 2).

The results of the estimation of the equation of the use of workers outside the family show that the use of workers outside the family is not responsive to changes in household income of rubber farmers outside the business (positive). However, the use of labor outside the family of rubber farmers in an effort is responsive to changes in the total outpouring of farmer work (negative).

Furthermore, the estimation results of the household income equation can be stated that the household income of rubber farmers outside the business is responsive to changes in household income of rubber farmers in the business (negative). However, the household income of rubber farmers outside the business is not responsive to changes in the outflow of rubber farming families outside the business (positive) (Table 2).

Furthermore, the results of estimating the expenditure of rubber farmer households shows that the food consumption of rubber farmer households is not responsive to changes in the number of rubber farmer family members (positive), rubber farmer household recreation expenses (positive) and the education of rubber farmer wives (negative). In the equation of non-food consumption of rubber farmer households shows that non-food consumption of rubber farmer households is not responsive to changes in the total income of rubber farmer households (positive), the number of rubber farmer family members (positive), education of rubber farmer wives (positive) and investment of farmer household education rubber (negative).

Table 2 shows the investment in education shows that the education investment of rubber farmer households is not responsive to changes in the number of school children of rubber farmer households (positive). Several studies on farm household economics show that household education expenditure is significantly influenced by the number of school children and total household income of farmers. Both variables are positively related to education expenditure (Adevia, Bakce, \& Hadi, 2017; Asrol \& Heriyanto, 2019; Husin \& Dwi Wulan, 2011; Khaswarina, 2017; Putra, Bakce, \& Rifai, 2012). Thus the results of this study are in accordance with the results of previous studies.

The equation of rubber farm household business investment it can be stated that the rubber farm household business investment is not responsive to changes in the total income of rubber farm households (positive) and the outflow of rubber farm family work in businesses (positive).Research result (Putra et al., 2012) shows the rubber farming investment variable is influenced by the total income of rubber farm households and the number of school children and is positively related. Both variables are not responsive to investment in rubber farming. Thus this research is similar (Adevia et al., 2017; Putra et al., 2012), where the income variable in farming is part of the total income of farm households.

Meanwhile, from the estimation results in the equation of rubber farmer household recreation expenditure it can be stated that the rubber farmer household recreation expenditure is responsive to changes in the outflow of rubber farm family work in businesses (negative), rubber farmer education (positive) and the education of rubber farmer wives (positive), but not responsive to changes in the outflow of rubber rubber family work outside the business (negative). Whereas based on the estimation results on the rubber farmer household saving equation it can be stated that the amount of rubber farmer household savings is responsive to changes in the total income of rubber farmer households (positive) but not responsive to changes in the total consumption of rubber farmer households (negative) and changes in interest rates (positive)

\section{Conclusion}

Based on the results of the previous analysis and discussion, conclusions can be drawn. The conclusions of this research are:

1) Characteristics of Rubber Farmers, the average age of rubber farmers at productive age (48 years), the length of education of rubber farmers 9 years, the education of the wife of rubber farmers 9 years, 16 years of farmer work experience, 6 household members, 4 farmers' labor force, number 2 school children, 2 hectares of land.

2) Internal factors of farm households are responsive to household economic decisions. There are no external factors included in the model that are responsive to the economic decisions of rubber farming households in Kuantan Singingi Regency regarding the aspects of production, working time allocation, income and expenditure of rubber farming households. From the aspect of production, no responsive internal or external factors were found, but the biggest effect was the number of productive rubber stems. From the aspect of work time allocation, internal factors that are responsive to influence are the total outpouring of farmer work, outpouring of farm family work in businesses and the workforce of farmer households. Furthermore, from the aspect of farmer's household income the responsive internal factors that influence it are the farmer's household income in the business. then what influences household expenditure is outflow of work in business, farmer education, wife education and total rubber farmer income.

\section{Acknowledgment}

The Biggest thanks to all colleagues during thedata collection and the parties involved in this research and the Universitas Islam Riau who permitted field observation, as well as the Direktorat Riset dan Pengabdian Masyarakat Dirjen Penguatan Riset dan Pengembangan Kementerian Riset, Teknologi dan Pendidikan. hopefully this journal can be useful as it should.

\section{References}

Adelman, I. (1984). Beyond export-led growth. World Development, 12(9), 937-949. Retrieved from https://econpapers.repec.org/RePEc:eee:wdevel:v:12:y: 1984:i:9:p:937-949

Adevia, J., Bakce, D., \& Hadi, S. (2017). Analisis Pengambilan Keputusan Ekonomi Rumah Tangga Petani Kelapa di Kecamatan Pulau Burung , Kabupaten Indragiri Hilir, 12(April), 11-24.

Asrol, A., \& Heriyanto, H. (2019). Structures of Revenue , Expenditure, And Welfare of Household Farmers in Kampar Regency , Riau Indonesia. WSEAS TRANSACTIONS on BUSINESS and ECONOMICS, 16(April), 1-8.

Asrol, A., \& Heriyanto, H. (2018). Daya saing ekspor pala indonesia di pasar internasional. Dinamika pertanian, 33(2), 61-70.

Badan Pusat Statistik. (2017a). Kampar Dalam Angka 2017. Bangkinang: Badan Pusat Statistik Kabupaten Kampar.

Badan Pusat Statistik. (2017b). Riau Dalam Angka 2017. Pekanbaru: Badan Pusat Statistik Provinsi Riau.

Barnum, H. N., \& Squire, L. (1978). An Econometric Application of the Theory of the Farm-Household. Journal of Development Economics, 6, 79-102.

Becker, G. . (1965). A Theory of Allocation of Time. Economic Journal, 299(75), 493-517.

Chuzaimah. (2006). Analisis Analisis Keragaan Ekonomi Rumahtangga Petani Peserta dan Non-Peserta Rice 
Estate dai Lahan Pasang Surut Delta Telang I Kabupaten Banyu Asin Sumatera Selatan. In Tesis Magister Sains. Bogor: Program Pascasarjana, Institut Pertanian Bogor.

Elinur. (2004). Analisis Sosial-Ekonomi Rumahtangga Industri Produk Jadi Rotan di Kota Pekanbaru. In Tesis Magister Sains. Program Pascasarjana, Institut Pertanian Bogor.

Elinur, \& Asrol. (2015a). Elinur dan Asrol. In Seminar Nasional: Krtalisasi Paradigma Agribisnis dalam Pembangunan Ekonomi dan Pendidikan Tinggi (pp. 5071). Bogor: Departemen Agribisnis Fakultas Ekonomi dan Manajemen. Institut Pertanian Bogor.

Elinur, \& Asrol. (2015b). Prilaku Ekonomi Rumahtangga Petani Kelapa Sawit di Desa Indra Sakti Kecamatan Tapung Kabupaten Kampar. In Prosiding Seminar Nasional: Krtalisasi Paradigma Agribisnis dalam Pembangunan Ekonomi dan Pendidikan Tinggi. Bogor: Departemen Agribisnis Fakultas Ekonomi dan Manajemen. Institut Pertanian Bogor.

Elinur, Asrol, \& Heriyanto. (2017). Household Economic Behavior of Rice Farmers Rambah Samo in District of Rokan Hulu Riau Province. In Proceeding International Conference on Science Engineering and Technology (ICoSET) and International Conference on Social Economic Education and Humaniora (ICoSEEH) (pp. 197-2011). Pekanbaru: Universitas Islam Riau.

Faradesi, E. (2004). Dampak Pasar Bebas Terhadap Prilaku Ekonomi Rumahtangga Petani Padi di Kabupaten Cianjur: Suatu Analisis Simulasi Model Ekonomi Rumahtangga Pertanian. Tesis Sekolah Pascasarjana Institut Pertanian Bogor. Bogor.

Heriyanto, H. (2016). Perilaku Konsumsi Pangan Sumber Karbohidrat Rumahtangga Petani Kelapa Sawit Di Kecamatan Kandis Kabupaten Siak. Jurnal Ilmiah Pertanian, 13(1), 22-30.

Heriyanto, H. (2017). Efficiency Of Rubber People Production In Kampar Regency Of Riau Province. In Proceeding International Conference on Science Engineering and Technology (ICoSET) and International Conference on Social Economic Education and Humaniora (ICoSEEH) (pp. 28-35). Pekanbaru: Universitas Islam Riau. Retrieved

from http://proceeding.uir.ac.id/conference/index.php?kate=I CoSEET.

Heriyanto, H. (2018). Permintaan Pangan Rumahtangga Provinsi Riau: Model Linear Approximate Almost Ideal Demand System. Jurnal Agribisnis, 20(2), 156-168.

Heriyanto, \& Asrol. (2019). Dominant factors affecting economic decisions in rubber farm households in Kampar Regency, Riau Province: The simultaneous equation model. International Journal of Innovation, Creativity and Change, 10(3), 185-200.

Heriyanto, H., Karya, D., \& Asrol, A. (2019). Indonesian coconut competitiveness in international markets. International Journal of Recent Technology and Engineering, $8(2$ Special Issue $), \quad 102-113$. https://doi.org/10.31580/apss.v1i3.390

Heriyanto, H., Karya, D., Choanji, T., Asrol, A., Bakce, D., \&Elinur, E. (2019). Regression Model in TransitionalGeologicalEnvironment For Calculation Farming andProductionof Oil PalmDominantFactor in Indragiri Hilir Riau Province. JournalofGeoscience, Engineering, Environment, and Technology, 4(1), 56-65.

Heriyanto, H., Asrol, A., Karya, D., \& Ningsih, V. Y. (2018). Analisis Faktor Produksi Kalapa Sawit Rakyat Menurut Tipologi Lahan di Kabupaten Indragiri Hilir Provinsi Riau. Jurnal Lahan Suboptimal, 7(1).

Husin, L., \& Dwi Wulan, S. (2011). Prilaku Ekonomi Rumahtangga Petani Karet di Pramubulih dalam Alokasi Tenaga Kerja, Produksi dan Konsumsi. Laporan Penelitian Bekerjasama Dengan Program Managing
Higher Education For Relevance and Efficiency (IMHERE. Bogor.

Husin, L., \& Sari, D, W. (2011). Perilaku Ekonomi Rumahtangga Petani Karet di Prabumulih dalam Alokasi Tenaga Kerja, Produksi dan Konsumsi. In Laporan Penelitian Indonesia Managing Higher Education For Relevance and Efficiency (I-MHERE). Jurusan Sosial Ekonomi Pertanian Fakultas Pertanian Universitas Sriwijaya. Palembang.

Jighan, M. . (1994). Ekonomi Pembangunan dan Perencanaan. Jakarta: PT. Grafindo Persada.

Julia, D., Asmara, A., \& SP M Si, H. (2016). Dampak Kebijakan Fiskal terhadap Kinerja Sektor Pertanian di Provinsi Riau. Dinamika Pertanian, 30(3), 233-248.

Karya, D., Heriyanto, \& Asrol. (2019). Response to supply and demand for indonesian palm oil in international markets: The simultaneous equation model approach. International Journal of Innovation, Creativity and Change, 10(3), 65-88.

Khaswarina, S. (2017). Faktor Dominan yang Mempengaruhi Ekonomi Rumahtangga Petani Karet di Desa Koto Damai Kabupaten Kampar. Jurnal Sosiohumaniora, 19(3), 199-205.

Koestiono, D. (2004). Analisis Analisis Ekonomi Rumahtangga Petani dalam Usaha Konservasi. In Tesis Magister Sains. Program Pascasarjana. Universitas Brawijaya. Malang.

Nakajima. (1989). ubjective Equilibrium Theory of The Farm Household. Elsevier Science Publisher. Amsterdam.

Heriyanto, \& Asrol. (2019). Dominant factors affecting economic decisions in rubber farm households in Kampar Regency, Riau Province: The simultaneous equation model. International Journal of Innovation, Creativity and Change, 10(3), 185-200.

Heriyanto, H., Karya, D., \& Asrol, A. (2019). Indonesian coconut competitiveness in international markets. International Journal of Recent Technology and Engineering, $8(2$ Special Issue $)$, 102-113. https://doi.org/10.31580/apss.v1i3.390

Karya, D., Heriyanto, \& Asrol. (2019). Response to supply and demand for indonesian palm oil in international markets: The simultaneous equation model approach. International Journal of Innovation, Creativity and Change, 10(3), 65-88.

Ningsih, V. Y., Wahyuni, N., Suryati, N., Noviyanto, N., \& Heriyanto, H. (2020). Competitiveness Sensitivity of Oil Palm Farming on Suboptimal Land at Musi Rawas Residence. Journal of Applied Agricultural Science and Technology, 4(1), 26-35. https://doi.org/10.32530/jaast.v4i1.147

Poonyth, D, R. Hassan, J. F. K., \& Calcaterra, M. (2001). Is Agricultural Sector Growth A Precondition for Economic Growth? The Case of South Africa. Agrecon, 40(2), 269-279.

Priyanti, A., B.M, S., Y.Syaukat, \& S.U, K. (2007). Model Ekonomi Rumahtangga Petani Pada Sistem Integrasi Tanaman-Ternak: Konsespsi dan Studi Empiris. Warta Noza, 17(2), 61-70.

Putra, A. Y., Bakce, D., \& Rifai, A. (2012). Pengaruh FaktorFaktor Internal dan Eksternal Terhadap Keputusan Ekonomi Rumahtangga Petani Karet di Kabupaten Kuantan Singingi. Indonesian Journal of Agricultural Economics (IJAE), 3(1), 71-83.

Rochaeni, S., \& Erna M, L. (2005). Faktor-Faktor yang Mempengaruhi Keputusan Ekonomi Rumahtangga Petani di Kelurahan Setugede Kota Bogor. Jurnal Agro Ekonomi, 23(2), 133-156.

Romeo, M, B. (2000). Agriculture-Based Development: A SAM Perspective on Central Vietnam Institute. TMD Discussion Paper, (51).

Romeo, M, B. (2001). Agriculture-Based Development: A 
SAM Perspective on Central Vietnam. The Developing Economies, 39(1), 112-132.

Singh, I., L. S., \& Strauss, J. (1986). Agricultural Household Models: Extension, Application and Policy. The John Hopkins University Press. Baltimore.

Siti, R., \& Erna, M. L. (2005). Faktor-Faktor Yang Mempengaruhi Keputusan Ekonomi Rumah Tangga Petani Di Kelurahan Setugede Kota Bogor. Jurnal Agro Ekonomi,

23(2) https://doi.org/http://dx.doi.org/10.21082/jae.v23n2.200 5.133-158.
Wahyudy, H. A., Khairizal, K., \& Heriyanto, H. (2019). Perkembangan Ekspor Karet Alam Indonesia. Dinamika Pertanian, 34(2), 1-8.

Warr, P. G. (2006). Productivity Growth in Thailand and Indonesia: How Agriculture Contributes to Economic Growth. In Working Papers in Economics and Development Studies. Bandung.

(C) (2) $\odot 2020$ Journal of Geoscience, Engineering, Environment and Technology. All rights reserved. This is an open access article distributed under the terms of the CC BY-SA License (http://creativecommons.org/licenses/by-sa/4.0/). 